Alexander Maringer

\title{
Weinrecht und Verbraucherschutz
}

Vom Alten Reich bis zur Gegenwart unter besonderer Berücksichtigung des Anbaugebiets Mosel

[Wine Law and Consumer Protection. From the Old Empire to the Present with a Focus on the Mosel Wine-Growing Region.]

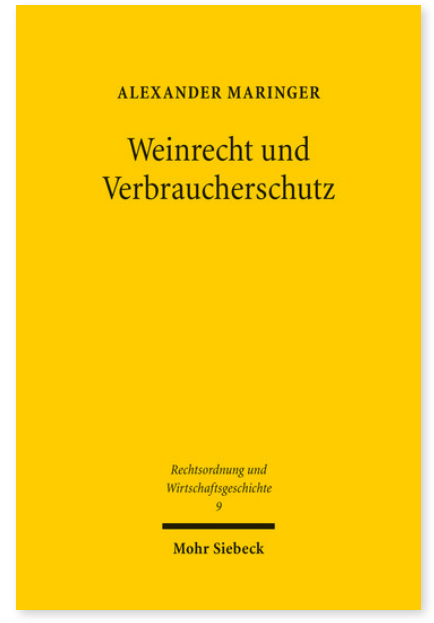

2014. XXII, 300 pages. ROWG 9

ISBN 978-3-16-153058-6

sewn paper $74,00 €$

ISBN 978-3-16-160614-4

eBook PDF 74,00€
Published in German.

From the perspective of the history of law, Alexander Maringer examines how the consumer was protected by statutory regulations in the past, what kind of protection he enjoys today and in particular whether the protection has improved constantly in the customer's favor.

Alexander Maringer Geboren 1978; Studium der Rechtswissenschaft in Trier; 2004 LL.M. Commercial and Business Law an der University of East Anglia in Norwich/Großbritannien; 2006 2. Staatsexamen im Landgerichtsbezirk Mainz (Rheinland-Pfalz); 2013 Promotion; 2007 Zulassung zur Rechtsanwaltschaft; Freier Mitarbeiter in einer Frankfurter Anwaltskanzlei; seit März 2011 Syndikus in der Rechtsabteilung eines international tätigen Unternehmens.

\section{Order now:}

https://www.mohrsiebeck.com/en/book/weinrecht-und-verbraucherschutz-9783161530586?no cache=1 order@mohrsiebeck.com

Phone: +49 (0)7071-923-17

Fax: +49 (0)7071-51104 